\title{
AKADEMIK DATA MINING (ADM) K-MEANS DAN K-MEANS K-NN UNTUK MENGELOMPOKAN KELAS MATA KULIAH KOSENTRASI MAHASISWA SEMESTER AKHIR
}

\author{
Suhardi Rustam ${ }^{1}$, Haditsah Annur ${ }^{2}$ \\ 1Suhardirstm@gmail.com, ${ }^{2}$ haditsah@gmail.com \\ 1,2Universitas Ichsan Gorontalo
}

\begin{abstract}
Abstrak
Universitas merupakan institusi pendidikan yang memegang peranan penting dalam menghasilkan lulusan. Selain itu, Institusi seperti universitas ichsan Gorontalo menyimpan kumpulan data. Data-data tersebut diantaranya tentang data akademik mahasiswa. Di bidang akademik, di setiap semester bertambahnya jumlah data yang direkam dengan data dari kegiatan akademik. Hal ini seperti adanya Tsunami data yang mengindikasikan bahwa data-data ini sangat melimpah namun tidak memberikan pengetahuan apapun sehingga tidak bermanfaat bagi universitas terutama fakultas kecuali pengetahuan administratif. Universitas Ichsan Gorontalo dengan jumlah mahasiswa mencapai 9000 orang yang disertai dengan jumlah lulusan yang masih kurang ideal setiap periode lulusan, maka perlu diterapkan pola penentuan kelas kosentrasi mata kuliah yang efektif bagi pencapai kemampuan mahasiswa, Data akademik yang akan digunakan yaitu data mahasiswa angkatan 20162017 yang telah mengambil kelas mata kuliah kosentrasi. Penerapan algoritma K-Means dan KMeans KNN dimana $\mathrm{K}=2$ mengahasilkan kluster untuk mengelompokkan Kelas Mata Kuliah Kosentrasi mahasiswa semester akhir dan masing-masing kluster tersebut memiliki nilai prediksi untuk kedua klustering tersebut, Nilai Akurasi yang dihasilkan Algoritma KNN yaitu nilai AUC (Area Under The Curve) $=1$, Nilai $C A=1$, nilai $F 1=1$, nilai Precision=1, dan Recall=1, serta nilai akurasi ini sebagai nilai terbaik.
\end{abstract}

Kata Kunci: Akademik Data Mining, K-Means, K-NN, akurasi AUC

\begin{abstract}
s
University as an educational institution plays an important role in producing graduates. In addition, institutions such as universitas ichsan Gorontalo save the data set. These Data include about student academic data.In the academic field, every semester, increasing the amount of data recorded with data from academic activities. It is like there is a Tsunami of data which indicate that these data are very abundant but do not give any knowledge that is not beneficial to the university, especially the faculty except the knowledge administrative. Universitas ichsan Gorontalo with the number of students reached 9000 people which is accompanied by the number of graduates is still less than ideal any period graduate, it is necessary to apply the pattern determination grade concentration courses effective for the achievement ability of students, academic Data will be used namely the data of the students 2016-2017 who has taken class subjects concentration. The application of K-Means algorithm and K-Means $\mathrm{KNN}$ where $\mathrm{K}=2$ result in a cluster for grouping of a Class Focus on the students semester end and each cluster has a predictive value for the second klustering such, the Value of the resulting Accuracy of Algorithms KNN, namely the AUC (Area Under The Curve) =1, the Value of $C A=1$, the value of $F 1=1$, the value of the precision=1 and recall=1, and the value of accuracy as the best value.
\end{abstract}

Keywords: Academic Data Mining, K-Means, K-NN, AUC accuracy

\section{Pendahuluan}

Universitas sebagai institusi pendidikan memegang peranan penting dalam menghasilkan lulusan dengan berbagai kemampuan sesuai visi misi dari institusi tersebut. Hal ini diperlukan usaha yang terukur dan konsisten dalam system pengajaran serta tata kelola yang baik sehingga sesuai dengan pedoman universitas. Demikian halnya data dalam institusi seperti universitas ichsan Gorontalo menyimpan kumpulan data yang banyak. Tsunami data mengindikasikan bahwa data-data ini sangat melimpah namun tidak memberikan pengetahuan apapun sehingga tidak bermanfaat bagi universitas terutama fakultas kecuali pengetahuan administratif. Supaya data ini bermanfaat maka data harus diolah terlebih dahulu menjadi pengetahuan [1]. Universitas Ichsan Gorontalo dengan jumlah mahasiswa mencapai 9000 orang yang disertai dengan jumlah lulusan yang masih kurang 


\section{ILKOM Jurnal IImiah Volume 11 Nomor 3 Desember 2019}

Terakreditasi peringkat 3 SK. No. 28/E/KPT/2019

ideal setiap periode lulusan, maka perlu diterapkan pola penentuan kelas kosentrasi mata kuliah yang efektif bagi pencapai kemampuan mahasiswa. Perlu digali informasi yang bisa digunakan untuk lebih meningkatkan ketepatan kelas kosentrasi yang salah satunya bisa jadi ukuran untuk menfokuskan kemampuan mahasiswa tersebut [2].

Data akademik yang akan digunakan yaitu data mahasiswa angkatan 2016-2017 yang telah mengambil kelas mata kuliah kosentrasi. Dan data ini juga sebagai data testing yang akan dicoba kedalam model algoritma klustering dan klasifikasi. Ada banyaknya algoritma yang digunakan untuk menyelesaikan persoalan pada data mining. Pada masalah universitas ini digunakan algoritma data mining yaitu algoritma klustering dan klasifikasi serta gabungan kedua algoritma tersebut. Algoritma klustering yang digunakan adalah K-Means dan algoritma perbandingannya dengan menggunkan gabungan algoritma yaitu K-Means K-NN. Algoritma K-Means [3] memiliki kelebihan yang dapat diterapkan dan dijalankan yang dapat diterapkan dan dijalankan untuk pengelompokan kelas mata kuliah kosentrasi yang ingin dirancang, relative cepat untuk di adaptasi, dan paling banyak dipraktekkan dalam data mining, algoritma ini merupakan algoritma sangat penting dalam data mining. Algoritma K-Means merupakan metode untuk mengelompokan objek atau data yang mempunyai atribut dan mempunyai jumlah data yang banyak kedalam bentu satu atau lebih kelompok sehingga data yang miliki karakteristik yang sama dikelompokan ke dalam satu cluster/kelompok yang sama [4].

K-Means dalam memilih bobot [5] dengan kemiripan [6] dan bebas memilih pusat kluster [7] karena pusat klusternya bebas [8] yang sering digunakan dalam penelitian [9] hal ini perlu di optimalkan hasilnya dengan K-NN di penelitian ini. K-NN dengan sifat $\mathrm{k}$ yaitu pemilihan tetangga terdekat, hasil K-Means juga akan mengoptimalkan K yang sifatnya bias[10]pada K-NN.

Penelitian ini akan menerapkan Algoritma K-Means dan Algoritma K-Means K-NN [11] dalam menentukan Kelas Mata Kuliah Kosentrasi Mahasiswa Semester Akhir dan bagaimana akurasi prediksi yang lebik akurat dan bermutu.

\section{Metode}

Penelitian ini menggunakan cara eksperimen dapat dilihat pada Gambar 1 dan Gambar 2. Penelitian dimulai dari pengumpulan dataset akademik mahasiswa sampai dengan mendapatkan hasil evaluasi dan hasil untuk mendapatkan tujuan yang akan dicapai.

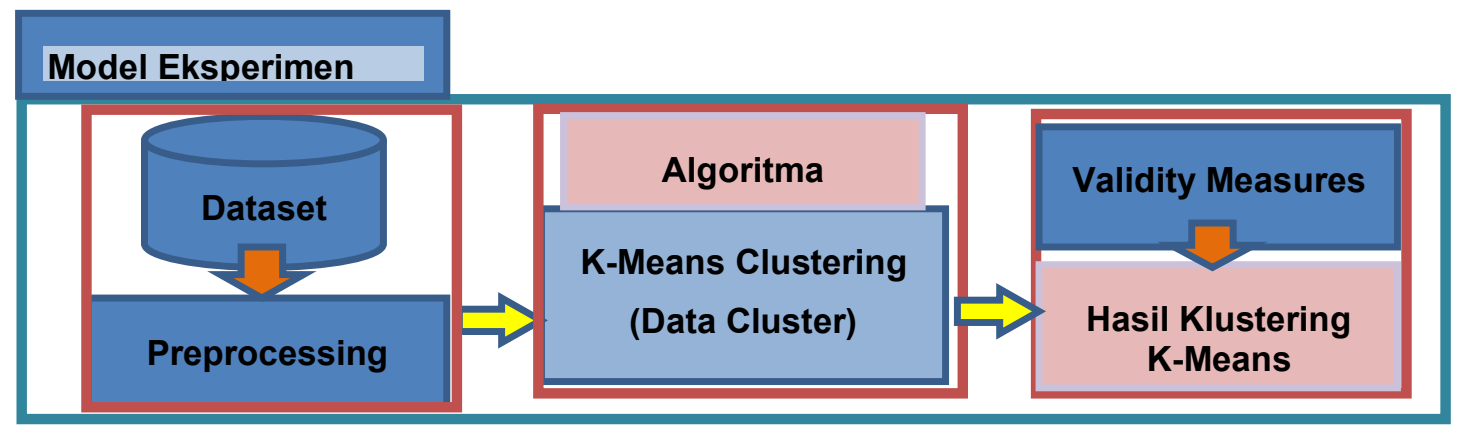

Gambar 1. Model Ekperimen fase Pertama, Model K-Means

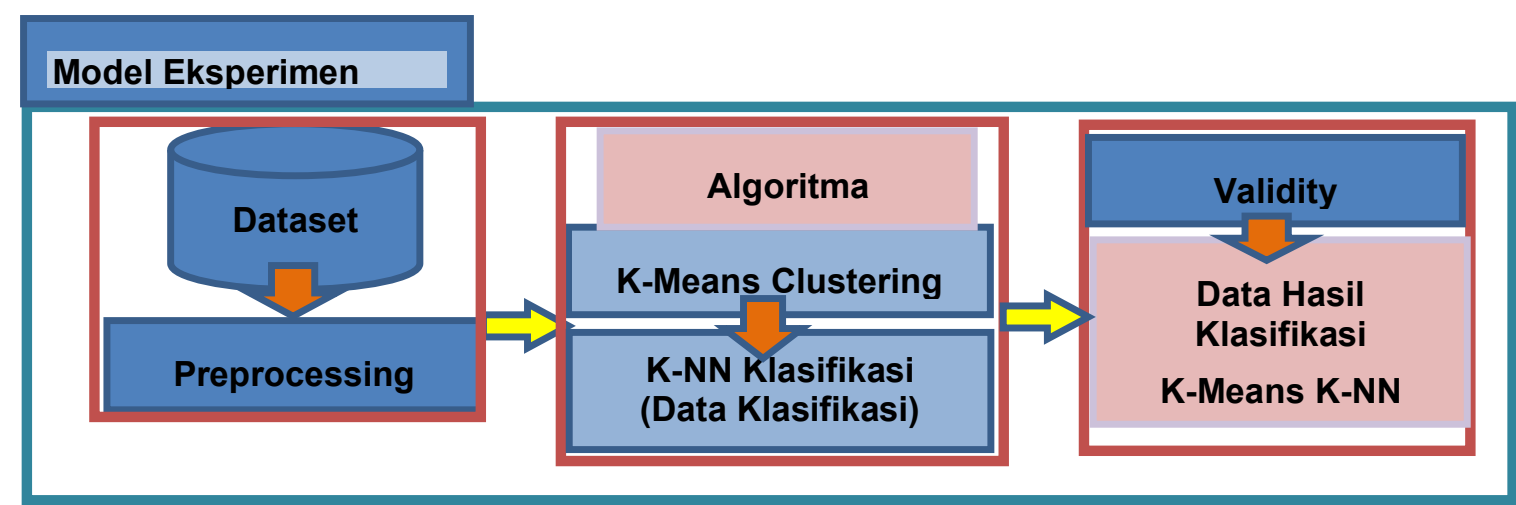

Gambar 2. Model Ekperimen fase Kedua, Model K-Means K-NN 
Tahapannya di mulai dari penyiapan dataset kemudian dilakukan langkah prepossessing terhadap data [12] untuk menghilangkan outlier-nya, selanjutnya adalah menormalisasikan data kemudian menggunakan tool data mining orange untuk mengelola data tersebut dengan menggunakan metode K-Means dan K-Means KNN [13]. Model yang digunakan pada penelitian ini ditunjukkan pada Gambar 1 yaitu model K-Means dan Gambar 2 menunjukkan model K-Means KNN.

\section{Pengumpulan Data}

Pada penelitian tersebut, yang data digunakan ini, juga diperoleh dari penelitian yang dilakuan pada data universitas ichsan Gorontalo yang berkaitan langsung dengan bagian pusat pengelolaan data kemahasiswaan universitas (BAAK Universitas). Identifikasi variable [14] dalam penelitian menentukan cara pengolahan data [15] dan alat yang digunakan untuk menganilis data [16]. Adapun variable dalam penelitian ini adalah sebagai berikut:

a. Indeks prestasi kumulatif, adalah penghitungan IP dengan menggabungkan semua mata kuliah yang telah ditempuh sampai suatu semester tertentu

b. Indesks prestasi semester, adalah nilai rata rata dari seluruh matakuliah yang telah diambil oleh mahasiswa

c. Nilai mata kuliah prasyarat konsentrasi, adalah nilai mata kuliah yang pelengkap untuk mata kuliah konsentrasi

d. Jumlah kehadiran dari mata kuliah prasyarat konsentrasi, merupakan nilai kehadiran mahasiswa dalam mengikuti mata kuliah tersebut

\section{Pengolahan Data Awal}

Penelitian ini dibatasi hanya pada tahapan ini melakukan preprocessing terhadap data untuk menghilangkan outlier [7] dan merapikan setiap variable yang terkait sehingga siap untuk ke tahap penggunaan selanjutnya.

\section{Eksperimen}

Ekperimen pada tahapan ini adalah menjalankan seluruh prosedur yang telah ditentukan/disusun dalam sebuah kerangka pemikirian untuk menyelesaikan masalah. Adapun tahapannya di mulai dari fase pertama yaitu penyiapan dataset kemudian dilakukan langkah prepossessing terhadap data untuk menghilangkan outliernya, selanjutnya adalah menormalisasikan data kemudian menggunakan tool rapidminer dan tools orange data mining untuk mengelola data tersebut dengan menggunakan metode $K$-Means clustering pada tahapan kelastering ini menggunakan jumlah kluster sebanyak $\mathrm{k}=2$, selanjutnya pada tahapan fase kedua yaitu penggunaan algoritma K-NN dengan nilai input dari hasil algoritma K-Means sehingga akan menghasilkan data klasifikasi.

Fase pertama, Secara umum algoritma dasar dari K-Means Clustering adalah sebagai berikut:

1. Tentukan jumlah cluster

2. Alokasikan data ke dalam cluster secara random

3. Hitung centroid/rata-rata dari data yang ada di masing-masing cluster

4. Alokasikan masing-masing data ke centroid/rata-rata terdekat

5. Kembali ke Step 3, apabila masih ada data yang berpindah cluster atau apabila perubahan nilai centroid, ada yang di atas nilai threshold yang ditentukan atau apabila perubahan nilai pada objective function yang digunakan di atas nilai threshold yang ditentukan.

Fase Kedua, secara umum algoritma dasar K-NN klasifikasi adalah sebagai berikut:

1. Input Nilai Awal

2. Menentukan parameter $\mathrm{K}$ sebagai banyaknya jumlah tetangga terdekat dengan objek baru.

3. Menghitung jarak antar objek/data baru terhadap semua objek/data yan gtelah di training.

4. Urutkan hasil perhitungan tersebut.dan Tentukan tetangga terdekat yang jarak minimum ke K.

5. Tentukan kategori dari tetangga terdekat dengan objek/data.

6. Gunakan kategori mayoritas sebagai klasifikasi objek/data baru

\section{Evaluasi}

Pengujian eksperimen yang dilakukan berupa eksperimen klustering pada algoritma K-Means dan eksperimen nilai akurasi AUC (Area Under The Curve) pada algoritma KNN. 
ILKOM Jurnal IImiah Volume 11 Nomor 3 Desember 2019

Terakreditasi peringkat 3 SK. No. 28/E/KPT/2019

3. Hasil dan Pembahasan

Tabel 1 menunjukkan deskripsi data eksperimen yang digunakan dalam penelitian ini.

Tabel 1. Deskripsi Data Eksperimen

\begin{tabular}{cll}
\hline No. & \multicolumn{1}{c}{ Nama Uraian } & \multicolumn{1}{c}{ Deskripsi } \\
\hline 1 & Dataset Data Akademik & $\begin{array}{l}\text { Nama dataset yang berisi sekumpulan data yang siap } \\
\text { digunakan dalam eksperimen }\end{array}$ \\
2 & Mahasiswa & Ukuran dataset dalam bentuk kolom dan baris \\
3 & Features & $\begin{array}{l}\text { Model data yang akan diproses seperti kategori dan } \\
\text { numeric } \\
\text { Variable dalam dataset yang akan dilewati dalam } \\
\text { pemrosesan data sepeti nim dan nama }\end{array}$ \\
\hline
\end{tabular}

\section{Preprocessing}

Pada tahapan preprocessing dapat dilihat pada Gambar 3, seluruh data harus menghilangkan outler/missing value yang tidak memilik nilai variable dalam dataset.

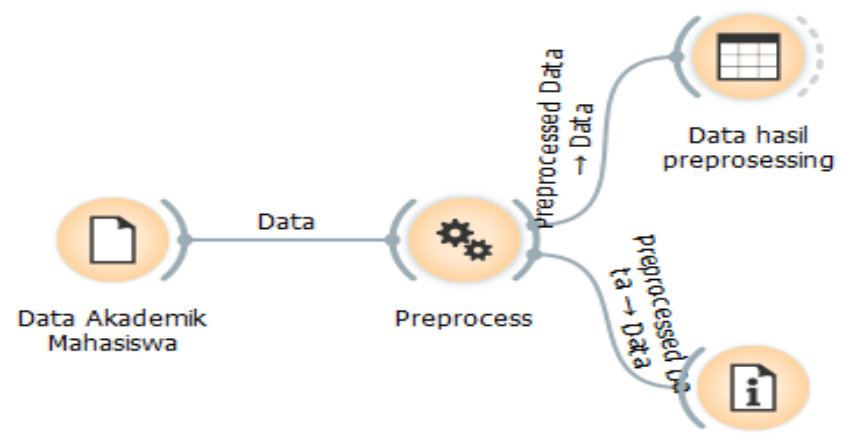

Info Data Experimen

Gambar 3. Tahapan preprocessing

Setelah melewati tahapan preprocessing, sebagian data tersebut ditampilkan pada Tabel 2.

Tabel 2. Hasil Preprocessing

\begin{tabular}{|c|c|c|c|c|c|c|c|c|c|}
\hline NIM & KLM & IPS1 & IPS2 & IPS3 & IPS4 & MK1 & H1 & MK2 & $\mathrm{H} 2$ \\
\hline T3116309 & P & 3.74 & 3.67 & 3.29 & 3.67 & 4 & 10 & 4 & 9 \\
\hline T3116312 & $\mathrm{P}$ & 4 & 3.88 & 4 & 3.75 & 3.9 & 9 & 3.6 & 9 \\
\hline T3116314 & $\mathrm{L}$ & 3.74 & 3.88 & 3.54 & 3.25 & 3.7 & 12 & 4 & 9 \\
\hline T3116315 & $\mathrm{L}$ & 3.74 & 3.63 & 3.79 & 3.67 & 3.9 & 13 & 4 & 9 \\
\hline T3116318 & $P$ & 3.65 & 3.88 & 3.54 & 3.75 & 3.7 & 12 & 3.9 & 9 \\
\hline T3116319 & $\mathrm{P}$ & 3.87 & 3.75 & 4 & 3.54 & 3.7 & 12 & 3.7 & 9 \\
\hline T3116320 & $\mathrm{P}$ & 3.65 & 3.75 & 3.54 & 3.75 & 4 & 12 & 3.9 & 9 \\
\hline T3116321 & L & 3.78 & 3.75 & 2.5 & 0 & 4 & 12 & 3.6 & 12 \\
\hline T3116323 & $\bar{L}$ & 3.78 & 3.63 & 3.42 & 3.67 & 3.7 & 12 & 3.6 & 12 \\
\hline T3116328 & $\mathrm{L}$ & 3.65 & 3.42 & 3.79 & 2.88 & 4 & 12 & 3.7 & 12 \\
\hline NIM & KLM & MK3 & H3 & MK4 & H4 & MK5 & H5 & MK6 & H6 \\
\hline T3116032 & L & 3.6 & 12 & 3.6 & 10 & 4 & 12 & 3.7 & 10 \\
\hline T3116309 & $\mathrm{P}$ & 3.7 & 12 & 3.9 & 9 & 4 & 12 & 4 & 9 \\
\hline T3116310 & $\mathrm{L}$ & 3.7 & 12 & 3.7 & 10 & 3.6 & 12 & 4 & 10 \\
\hline T3116312 & $\mathrm{P}$ & 4 & 12 & 3.9 & 9 & 3.9 & 12 & 3.7 & 9 \\
\hline T3116314 & $\mathrm{L}$ & 4 & 12 & 4 & 9 & 3.7 & 12 & 4 & 9 \\
\hline
\end{tabular}


ILKOM Jurnal IImiah Volume 11 Nomor 3 Desember 2019

Terakreditasi peringkat 3 SK. No. 28/E/KPT/2019

\begin{tabular}{|c|c|c|c|c|c|c|c|c|c|}
\hline NIM & KLM & IPS1 & IPS2 & IPS3 & IPS4 & MK1 & H1 & MK2 & $\mathrm{H} 2$ \\
\hline T3116315 & $\mathrm{L}$ & 3.7 & 12 & 3.7 & 9 & 3.9 & 12 & 4 & 9 \\
\hline T3116316 & $\mathrm{P}$ & 4 & 12 & 4 & 9 & 3.6 & 12 & 3.6 & 9 \\
\hline T3116317 & $\mathrm{L}$ & 4 & 12 & 4 & 9 & 3.6 & 12 & 4 & 9 \\
\hline T3116318 & $\mathrm{P}$ & 3.6 & 12 & 3.6 & 9 & 3.7 & 12 & 4 & 9 \\
\hline T3116319 & $\mathrm{P}$ & 4 & 12 & 4 & 10 & 3.7 & 12 & 4 & 9 \\
\hline T3116320 & $P$ & 4 & 12 & 4 & 9 & 4 & 12 & 3.6 & 9 \\
\hline T3116321 & $\mathrm{L}$ & 4 & 12 & 4 & 10 & 4 & 12 & 3.9 & 12 \\
\hline T3116323 & $\mathrm{L}$ & 3.6 & 12 & 3.6 & 9 & 3.7 & 12 & 3.7 & 12 \\
\hline T3116324 & L & 3.9 & 12 & 3.9 & 9 & 4 & 12 & 3.9 & 12 \\
\hline T3116325 & $\mathrm{L}$ & 3.7 & 12 & 3.7 & 9 & 3.7 & 12 & 3.6 & 12 \\
\hline T3116326 & $\mathrm{L}$ & 3.9 & 12 & 3.9 & 9 & 4 & 12 & 3.6 & 12 \\
\hline T3116327 & $\mathrm{L}$ & 4 & 12 & 4 & 9 & 4 & 12 & 3.7 & 12 \\
\hline T3116328 & $\mathrm{L}$ & 3.7 & 12 & 4 & 9 & 3.7 & 12 & 3.7 & 12 \\
\hline
\end{tabular}

\section{Algoritma K-Means}

Dalam model eksperimen ini, algoritma K-Means ditempatkan setelah data preprocessing. Gambar 4 menunjukkan model K-Means yang digunakan.

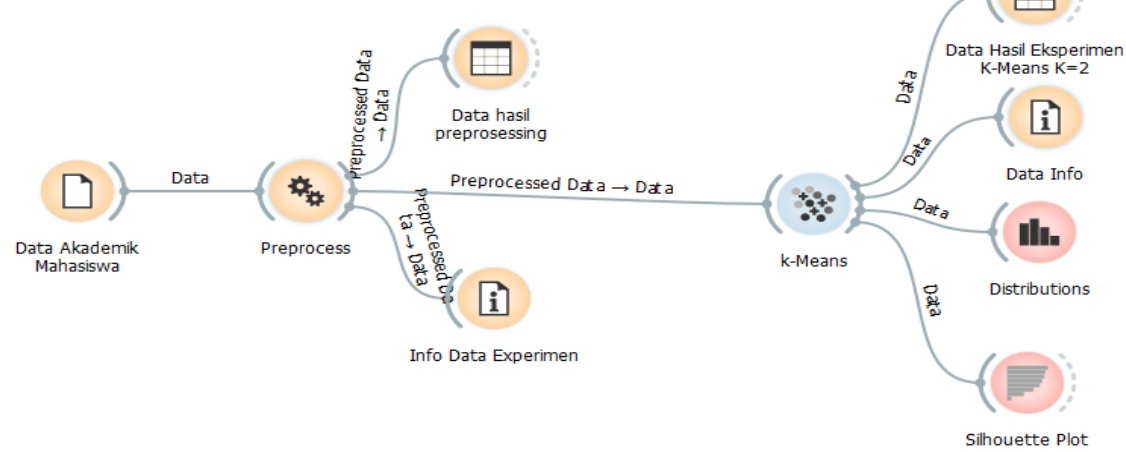

Gambar 4. Model K-Means

Model K-Means menghasilkan kluster yaitu Kluster C1 dan Kluster C2 dengan grafik frekuensi kluster pada Gambar 5. Gambar 6 adalah grafik silhouette kluster yang menunjukkan kerapatan data kluster (relative density) dengan jarak antara garis/jarak dari setiap pinggiran kluster.

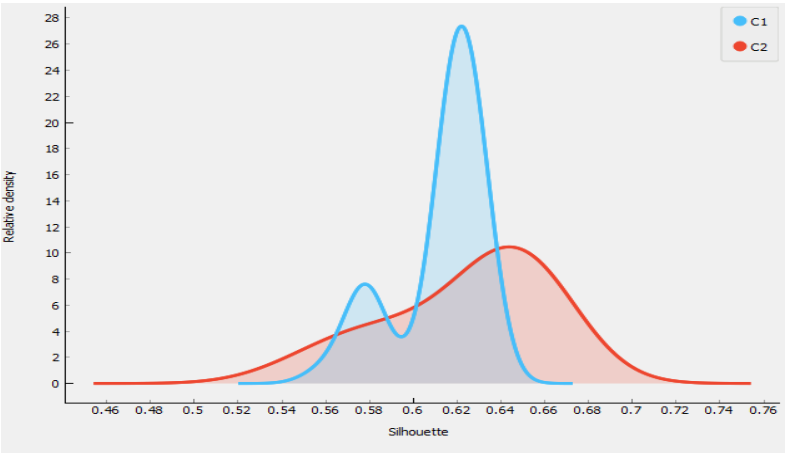

Gambar 5. Grafik frekuensi kluster

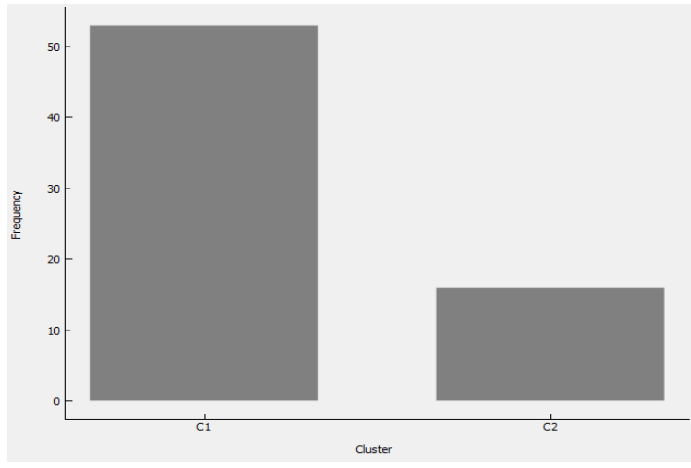

Gambar 6. Grafik Silhouette Kluster

Hasil eksperimen akademik data akademik menggunakan algoritma K-Means ditampilkan pada Tabel 3.

Table 3. Hasil Eksperimen dengan K-Means

\begin{tabular}{llll}
\hline No & Algoritma & Uraian & Keterangan \\
\hline 1. & K-Means & $\mathrm{K}=2$ & $\begin{array}{l}\text { Jumlah kluster yang digunakan } \\
\text { adalah 2 (dua) yaitu K=2 } \\
\end{array}$ \\
& Attribute C1 dan C2 & $\begin{array}{l}\text { Merupakan attribute klustering yang } \\
\text { di miliki yaitu C1 dan C2 }\end{array}$ \\
\hline
\end{tabular}


ILKOM Jurnal IImiah Volume 11 Nomor 3 Desember 2019

Terakreditasi peringkat 3 SK. No. 28/E/KPT/2019

$$
\begin{aligned}
& \text { Dataset }=69 \text { record } \\
& C 1=53 \text { record } \\
& C 2=16 \text { record }
\end{aligned}
$$

Silhouette
Adalah jumlah record dalam dataset yang memiliki kluster $\mathrm{C} 1$ sejumlah 53 record dan C2 sejumlah 16 record

Yaitu nilai variable dari jarak tepi luar variable dengan pusat masingmasing kluster

\section{Algoritma K-Means dan K-NN}

Gambar 7 menunjukkan model eksperimen yang digunakan yaitu dataset diperoleh dari data hasil $\mathrm{K}-M e a n s$ dengan $\mathrm{K}=2$, yang selanjutnya menjadi dataset untuk eksperimen dengan menggunkan $\mathrm{KNN}$ (K-Means KNN) dengan K=2. Model data prediksi akan memberikan output berupa prediksi dan probabilitas klasifikasi data, sehingga dapat menghasilkan data seperti pada Tabel 4.

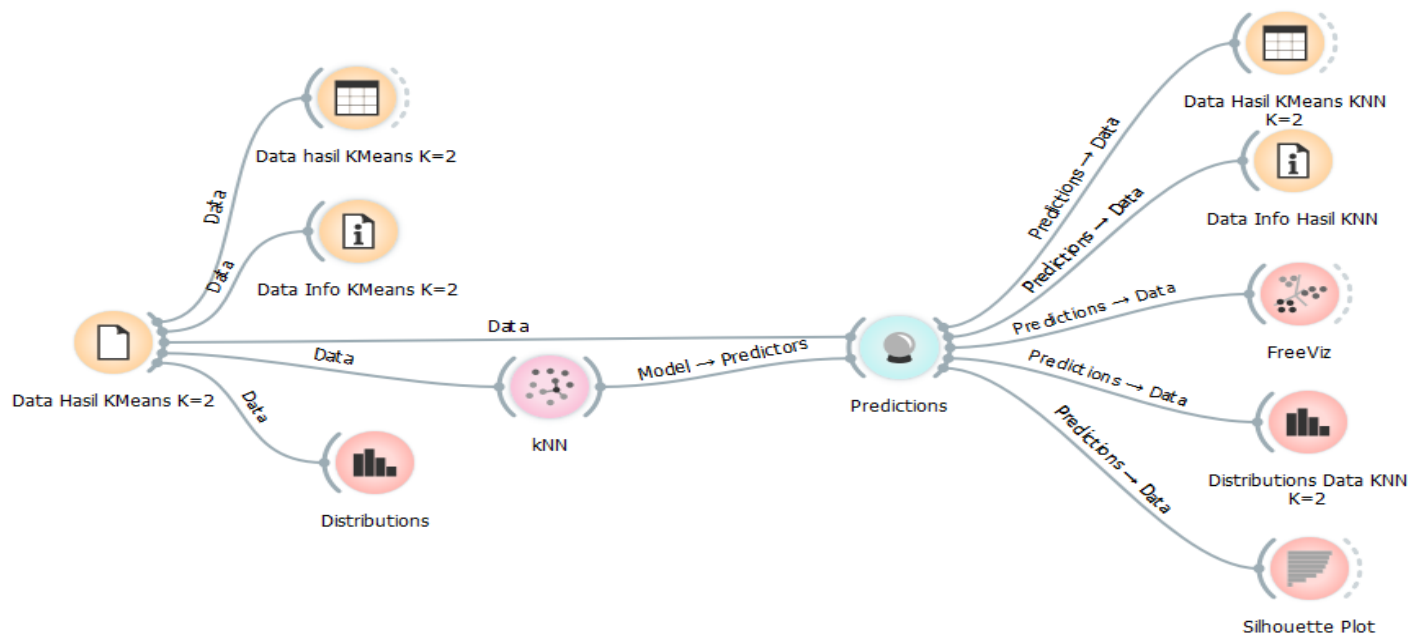

\begin{tabular}{|c|c|c|c|c|c|c|c|c|c|c|c|}
\hline NIM & CLUSTER & SIL & KLM & IPS1 & IPS2 & IPS3 & IPS4 & MK1 & H1 & MK2 & $\mathrm{H} 2$ \\
\hline T3116032 & C1 & 0.586027 & $\mathrm{~L}$ & 2.52 & 1.88 & 3.36 & 2.79 & 4 & 12 & 3.7 & 10 \\
\hline T3116309 & $\mathrm{C} 1$ & 0.568574 & $\mathrm{P}$ & 3.74 & 3.67 & 3.29 & 3.67 & 4 & 10 & 4 & 9 \\
\hline T3116310 & $\mathrm{C} 1$ & 0.60163 & L & 3.65 & 3.67 & 4 & 3.67 & 3.6 & 13 & 4 & 10 \\
\hline T3116312 & C1 & 0.557939 & $P$ & 4 & 3.88 & 4 & 3.75 & 3.9 & 9 & 3.6 & 9 \\
\hline T3116314 & C1 & 0.579563 & L & 3.74 & 3.88 & 3.54 & 3.25 & 3.7 & 12 & 4 & 9 \\
\hline T3116315 & $\mathrm{C} 1$ & 0.575699 & L & 3.74 & 3.63 & 3.79 & 3.67 & 3.9 & 13 & 4 & 9 \\
\hline T3116316 & $\mathrm{C} 1$ & 0.577392 & $\mathrm{P}$ & 4 & 3.88 & 4 & 3.75 & 3.6 & 12 & 4 & 9 \\
\hline T3116317 & $\mathrm{C} 1$ & 0.579583 & L & 3.87 & 3.88 & 3.71 & 3.67 & 3.6 & 12 & 3.6 & 9 \\
\hline T3116318 & $\mathrm{C} 1$ & 0.578649 & $P$ & 3.65 & 3.88 & 3.54 & 3.75 & 3.7 & 12 & 3.9 & 9 \\
\hline T3116319 & C1 & 0.577618 & P & 3.87 & 3.75 & 4 & 3.54 & 3.7 & 12 & 3.7 & 9 \\
\hline T3116320 & $\mathrm{C} 1$ & 0.578626 & $\mathrm{P}$ & 3.65 & 3.75 & 3.54 & 3.75 & 4 & 12 & 3.9 & 9 \\
\hline T3116321 & C1 & 0.578992 & L & 3.78 & 3.75 & 2.5 & 0 & 4 & 12 & 3.6 & 12 \\
\hline T3116323 & C1 & 0.618505 & L & 3.78 & 3.63 & 3.42 & 3.67 & 3.7 & 12 & 3.6 & 12 \\
\hline T3116324 & C1 & 0.617951 & L & 3.87 & 3.75 & 4 & 3.75 & 4 & 12 & 3.7 & 12 \\
\hline T3116325 & $\mathrm{C} 1$ & 0.619241 & L & 3.74 & 3.54 & 3.5 & 3.5 & 4 & 12 & 3.7 & 12 \\
\hline T3116326 & C1 & 0.616556 & L & 3.65 & 3.17 & 3.21 & 3.33 & 3.6 & 12 & 4 & 12 \\
\hline T3116327 & $\mathrm{C} 1$ & 0.618326 & L & 3.65 & 3.75 & 3.79 & 3.75 & 4 & 12 & 4 & 12 \\
\hline T3116328 & $\mathrm{C} 1$ & 0.61652 & L & 3.65 & 3.42 & 3.79 & 2.88 & 4 & 12 & 3.7 & 12 \\
\hline Т3116329 & $\mathrm{C} 1$ & 0.613568 & $P$ & 4 & 3.75 & 3.79 & 3.75 & 4 & 12 & 4 & 12 \\
\hline $\begin{array}{l}\text { T3116330 } \\
\text { T3116332 }\end{array}$ & $\begin{array}{l}\mathrm{C} 1 \\
\mathrm{C} 1\end{array}$ & $\begin{array}{c}0.61307 \\
0.618189\end{array}$ & $\begin{array}{l}P \\
P\end{array}$ & $\begin{array}{l}3.61 \\
3.87\end{array}$ & $\begin{array}{l}3.42 \\
3.75\end{array}$ & $\begin{array}{l}3.42 \\
3.42\end{array}$ & $\begin{array}{l}3.04 \\
3.75\end{array}$ & $\begin{array}{l}3.6 \\
3.9\end{array}$ & $\begin{array}{l}12 \\
12\end{array}$ & $\begin{array}{c}4 \\
3.6\end{array}$ & $\begin{array}{l}12 \\
12\end{array}$ \\
\hline NIM & CLUSTER & SIL & KLM & MK3 & H3 & MK4 & $\mathrm{H} 4$ & MK5 & H5 & MK6 & H6 \\
\hline T3116032 & C1 & 0.586027 & $\mathrm{~L}$ & 3.6 & 12 & 3.6 & 10 & 4 & 12 & 3.7 & 10 \\
\hline
\end{tabular}

Gambar 7. Model Eksperimen KNN (Kmean KNN) dengan K=2

Tabel 4. Data Hasil KNN dengan $\mathrm{K}=2$ 
ILKOM Jurnal IImiah Volume 11 Nomor 3 Desember 2019

Terakreditasi peringkat 3 SK. No. 28/E/KPT/2019

\begin{tabular}{|c|c|c|c|c|c|c|c|c|c|c|c|}
\hline NIM & CLUSTER & SIL & KLM & MK3 & H3 & MK4 & H4 & MK5 & H5 & MK6 & H6 \\
\hline T3116309 & C1 & 0.568574 & $\mathrm{P}$ & 3.7 & 12 & 3.9 & 9 & 4 & 12 & 4 & 9 \\
\hline T3116310 & C1 & 0.60163 & $\mathrm{~L}$ & 3.7 & 12 & 3.7 & 10 & 3.6 & 12 & 4 & 10 \\
\hline T3116312 & C1 & 0.557939 & $\mathrm{P}$ & 4 & 12 & 3.9 & 9 & 3.9 & 12 & 3.7 & 9 \\
\hline T3116314 & C1 & 0.579563 & $\mathrm{~L}$ & 4 & 12 & 4 & 9 & 3.7 & 12 & 4 & 9 \\
\hline T3116315 & C1 & 0.575699 & $\mathrm{~L}$ & 3.7 & 12 & 3.7 & 9 & 3.9 & 12 & 4 & 9 \\
\hline T3116316 & C1 & 0.577392 & $\mathrm{P}$ & 4 & 12 & 4 & 9 & 3.6 & 12 & 3.6 & 9 \\
\hline T3116317 & C1 & 0.579583 & $\mathrm{~L}$ & 4 & 12 & 4 & 9 & 3.6 & 12 & 4 & 9 \\
\hline T3116318 & C1 & 0.578649 & $\mathrm{P}$ & 3.6 & 12 & 3.6 & 9 & 3.7 & 12 & 4 & 9 \\
\hline T3116319 & C1 & 0.577618 & $\mathrm{P}$ & 4 & 12 & 4 & 10 & 3.7 & 12 & 4 & 9 \\
\hline T3116320 & C1 & 0.578626 & $\mathrm{P}$ & 4 & 12 & 4 & 9 & 4 & 12 & 3.6 & 9 \\
\hline T3116321 & C1 & 0.578992 & $\mathrm{~L}$ & 4 & 12 & 4 & 10 & 4 & 12 & 3.9 & 12 \\
\hline T3116323 & C1 & 0.618505 & $\mathrm{~L}$ & 3.6 & 12 & 3.6 & 9 & 3.7 & 12 & 3.7 & 12 \\
\hline T3116324 & C1 & 0.617951 & $\mathrm{~L}$ & 3.9 & 12 & 3.9 & 9 & 4 & 12 & 3.9 & 12 \\
\hline T3116325 & C1 & 0.619241 & $L$ & 3.7 & 12 & 3.7 & 9 & 3.7 & 12 & 3.6 & 12 \\
\hline T3116326 & C1 & 0.616556 & $L$ & 3.9 & 12 & 3.9 & 9 & 4 & 12 & 3.6 & 12 \\
\hline T3116327 & C1 & 0.618326 & $L$ & 4 & 12 & 4 & 9 & 4 & 12 & 3.7 & 12 \\
\hline T3116328 & $\mathrm{C} 1$ & 0.61652 & $\mathrm{~L}$ & 3.7 & 12 & 4 & 9 & 3.7 & 12 & 3.7 & 12 \\
\hline T3116329 & C1 & 0.613568 & $\mathrm{P}$ & 4 & 12 & 3.6 & 9 & 4 & 12 & 4 & 12 \\
\hline T3116330 & C1 & 0.61307 & $\mathrm{P}$ & 4 & 12 & 3.9 & 9 & 4 & 12 & 4 & 12 \\
\hline T3116332 & C1 & 0.618189 & $P$ & 3.6 & 12 & 3.7 & 12 & 3.6 & 12 & 3.7 & 12 \\
\hline
\end{tabular}

Distribusi data hasil KNN dengan K=2 ditunjukkan pada Gambar 8.

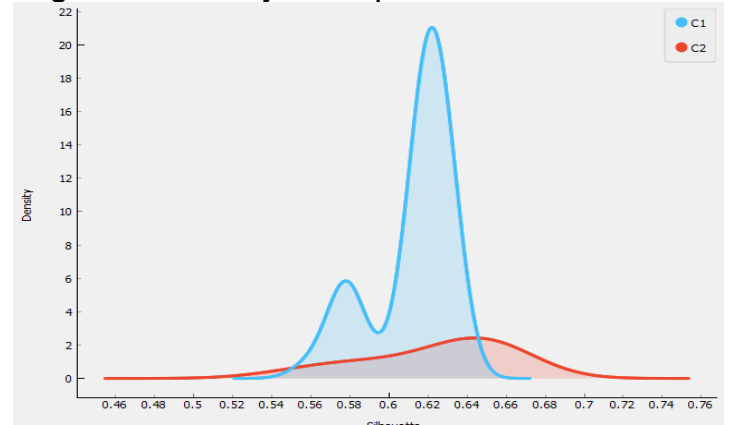

Gambar 8. Grafik Distribusi K-MEANS KNN

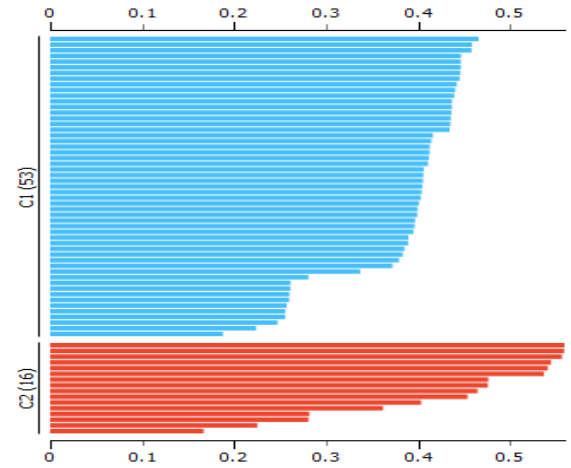

Gambar 9. Grafik Silhuoette Plot K-MEANS KNN

Gambar 9 adalah model Silhouette plot mengenai jarak data (distance) terhadap kluster, di bawah ini merupahan grafik gambaran nilai silhouette plot terhadap kluster pada KNN dimana $\mathrm{k}=2$

\section{Akurasi data hasil K-Means KNN dimana K=2}

Model klasifikasi dengan KNN dengan menggunakan data cluster K-Means menghasilkan akurasi prediksi dengan nilai $A U C=1$, Nilai $C A=1$, nilai $F 1=1$, nilai Precision=1, dan Recall=1, serta nilai akurasi ini sebagai nilai terbaik untuk nilai ini dapat dilihat pada Gambar 10. 
ILKOM Jurnal IImiah Volume 11 Nomor 3 Desember 2019 Terakreditasi peringkat 3 SK. No. 28/E/KPT/2019

$$
\begin{array}{|l|c|c|c|c|c|}
\hline \text { Model } & \text { AǓC } & \text { CA } & \text { F1 } & \text { Precision } & \text { Recall } \\
\text { kNN } & 1.000 & 1.000 & 1.000 & 1.000 & 1.000 \\
\multicolumn{4}{c}{\text { Gambar 10. Akurasi Data pada KNN }}
\end{array}
$$

\begin{abstract}
Melihat data hasil eksperimen dengan menggunakan dataset Akademik Mahasiswa dalam eksperimen ini, pada tahap pemodelan dengan menggunakan algoritma $\mathrm{K}-M e a n s$ dengan $\mathrm{K}=2$, data tersebut dapat terkluster sebagai $\mathrm{C} 1$ dengan jumlah record 53 record dan $\mathrm{C} 2$ dengan jumlah 16 record, dari hasil klustering ini dapat diketahui kelompok konsentrasi mata kuliah jurusan, pada tahapan ini juga diperlukan model KNN untuk memprediksi yang lebih baik kelompok klustering ini, dengan model klasifikasi KNN dengan menggunakan dataset data hasil K-Means pada model ini didapat nilai akurasi yang lebih baik dengan nilai $A U C=1$, Nilai $C A=1$, nilai $F 1=1$, nilai Precision=1, dan Recall=1 untuk kedua klustering tersebut, serta nilai akurasi ini sebagai nilai terbaik, nilai ini dapat dilihat pada gambar 4.9, adapun hasil eksperimen dari dataset akademik data mining dengan algoritma K-Means dan K-Means Knn dimana k=2 seperti Table 5.
\end{abstract}

Table 5. Hasil eksperimen data mining dengan K-Means dan K-Means KNN, K=2

\begin{tabular}{llrrrrr}
\hline No & Model & K & Kluster & AUC & Precision & Recall \\
\hline 1. & K-Means & 2 & C1,C2 & - & - & - \\
2. & K-Means KNN & 2 & C1,C2 & 1 & 1 & 1 \\
\hline
\end{tabular}

\title{
4. Kesimpulan dan Saran
}

Sebagaimana dalam uraian pembahasan penelitian ini, dapat disimpulkan sebagai berikut, Penerapan algoritma K-Means dan K-Means KNN dimana $\mathrm{K}=2$ mengahasilkan kluster untuk mengelompokkan Kelas Mata Kuliah Kosentrasi mahasiswa semester akhir dan masing-masing kluster tersebut memiliki nilai prediksi untuk kedua klustering tersebut dan Nilai Akurasi yang dihasilkan Algoritma KNN yaitu nilai AUC (Area Under The Curve) $=1$, Nilai $\mathrm{CA}=1$, nilai $\mathrm{F} 1=1$, nilai Precision $=1$, dan Recall $=1$, serta nilai akurasi ini sebagai nilai terbaik. Adapun saran dalam penelitian ini, untuk keperluan lebih lanjut data mining dalam pengolahan data akademik mahasiswa, maka disarankan untuk menguji coba disetiap iterasi dikarenakan dalam eksperimen ini fokus menggunakan $\mathrm{k}=2$, penelitian semacam ini dapat dikembangkan dengan menggunakan optimasi di masing-masing algoritma.

\section{Ucapan Terima Kasih}

Saya mengucapkan banyak terima kasih atas bimbingan dari rekan-rekan di Lembaga Penelitian (LEMLIT) Universitas Ichsan Gorontalo dan juga dari rekan sesama dosen dan peneliti di fakultas ilmu komputer, semoga keilmuan di bidang ilmu komputer selalu dikembangkan dan diteliti dengan bidang fokus masing-masing.

\section{Daftar Pustaka}

[1] Agarwal, S., Data mining: Data mining concepts and techniques. Proceedings - 2013 International Conference on Machine Intelligence Research and Advancement (ICMIRA 2013), https://doi.org/10.1109/ICMIRA.2013.45, 2014.

[2] Banjarsari, M. A., Budiman, I., \& Farmadi, A. "Penerapan K-Optimal Pada Algoritma Knn Untuk Prediksi Kelulusan Tepat Waktu Mahasiswa Program Studi IImu Komputer Fmipa Unlam Berdasarkan Ip Sampai Dengan Semester 4." Klik - Kumpulan Jurnal IImu Komputer, 2(2), 159173. https://doi.org/10.20527/KLIK.V2I2.26, 2018.

[3] Nur, F., Fauzan, R., Aziz, J., Setiawan, B. D., \& Arwani, I., "Implementasi Algoritma K-Means untuk Klasterisasi Kinerja Akademik Mahasiswa", Jurnal Pengembangan Teknologi Informasi Dan Ilmu Komputer, 2(6), 2243-2251, 2018.

[4] Pradnyana, G. A., Aan, A., \& Permana, J., "Perbandingan Algoritma K-Means dan Hybrid KMeans KNN untuk Pembagian Kelas Kuliah Mahasiswa", Senari, 1-8, 2017.

[5] I. G. Ayu and D. Saryanti, "Penerapan Teknik Clustering untuk Pengelompokan Konsentrasi Mahasiswa dengan Metode K-Means" pp. 519-526, 2019.

[6] T. A. Munandar and W. O. Widyarto, "Clustering Data Nilai Mahasiswa Untuk Pengelompokan Konsentrasi Jurusan Menggunakan Fuzzy Cluster Means," Semin. Nas. Apl. Teknol. Inf., pp. 
1907-5022, 2013.

[7] Widodo and D. Wahyuni, "Implementasi algoritma K-Means clustering untuk mengetahui bidang skripsi mahasiswa multimedia pendidikan teknik informatika dan komputer universitas negeri jakarta," J. Pint., vol. 01, No. September, p. 11 pages, 2018.

[8] A. Rizky and F. Amiq, "Penerapan Metode Clustering Dengan Algoritma K- Means Untuk Rekomendasi Pemilihan Jalur Peminatan Sesuai Kemampuan Pada Program Studi," 2013.

[9] P. S. Informatika, U. T. Yogyakarta, and S. P. "Keputusan Pada Universitas Swadaya Gunung Djati Menggunakan Metode K-Means Clustering" pp. 1-10.

[10] K. N. Sistem, G. A. Pradnyana, A. Aan, J. Permana, and U. P. Ganesha, "Perancangan Sistem Pembagian Kelas Kuliah Mahasiswa dengan Kombinasi Metode K-Means dan K-Nearest," pp. 285-290, 2017.

[11] Rohman, A. (2015). Model Algoritma K-Nearest Neighbor (K-Nn) Untuk Prediksi Kelulusan Mahasiswa. Neo Teknika, 1(1). https://doi.org/10.1017/CBO9781107415324.004

[12] Rustam, S., "Analisa Clustering Phising Dengan K-Means Dalam Meningkatkan Keamanan Komputer", ILKOM Jurnal IImiah, 10(2), 175. https://doi.org/10.33096/ilkom.v10i2.309.175-181, 2018.

[13] Rustam, S., Santoso, H. A., \& Supriyanto, C., "Optimasi K-Means Clustering Untuk Identifikasi Daerah Endemik Penyakit Menular Dengan Algoritma Particle Swarm Optimization Di Kota Semarang." ILKOM Jurnal IImiah, 10 (3), 251. https://doi.org/10.33096/ilkom.v10i3.342.251-259, 2018.

[14] J. Han, Data Mining: Concepts and Techniques (The Morgan Kaufmann Series in Data Management Systems), 2011.

[15] G. I. Marthasari, "Implementasi Teknik Data Mining untuk Evaluasi Kinerja Mahasiswa Berdasarkan Data Akademik," Fountain Informatics J., vol. 2, no. 2, p. 20, 2017. 